\title{
Análise sobre a obra Latifúndio, Escravidão $e$ Dependência Econômica de Ramiro Guerra
}

\author{
Analysis of the work of Ramiro Guerra: Latifundia, \\ Slavery and Economic Dependence
}

CINARA BARBOSA FRANCO DE SÁ*; IZAMARA NUNES SOUSA*\%,

\begin{abstract}
RESUMO: Este trabalho tem como objetivo analisar a obra de Ramiro Guerra (Latifúndio, escravidão e dependência econômica), uma das suas principais obras que trata da região de Barbados localizada nas Pequenas Antilhas na América Central. Assim, a análise mostra como Ramiro Guerra desmistifica toda uma teoria em relação à substituição do trabalho do pequeno proprietário pela mão de obra barata do escravo. O mesmo autor ressalta que essa substituição não foi devido a uma questão de raças ou de clima ou até mesmo da superioridade da vontade humana. Mas, sim, devido a uma causa puramente social e econômica: a destruição da pequena propriedade pelo latifúndio açucareiro e pela conseguinte emigração de uma classe social que seria expulsa de forma "voluntária" devido à falta de trabalho. Dessa forma, a análise, de acordo com o pensamento de Guerra, enfatiza que não foi o clima antilhano que expulsou os servos brancos, mas sim a empresa açucareira capitalista que se instalaria na região, aniquilando a pequena propriedade e eliminando o cultivador independente e convertendo as comunidades robustas com vidas próprias em meras oficinas de trabalho com salários baixos, tudo em prol das metrópoles. E também as consequências desse comércio açucareiro em Cuba trazendo as mesmas consequências de destruição da pequena agricultura.
\end{abstract}

PALAVRAS-CHAVE: Latifúndio; Trabalho; Agricultura; Economia.

ABSTRACT: This work aims to analyze the work of Ramiro Guerra (Latifundia, slavery and economic dependence), one of his main works dealing with the region of Barbados located

\footnotetext{
* Bacharela em Serviço Social pela Universidade Federal do Maranhão - UFMA, São Luiz -MA, Brasil. E-mail: cinarafs2001@yahoo.com.br

- Aluna do Programa de Pós Graduação em Desenvolvimento Socioespacial e Regional da Universidade Estadual do Maranhão. Bolsista pela FAPEMA

** Bacharela em Serviço Social pela Universidade Federal do Maranhão - UFMA, São Luiz - MA, Brasil. E-mail: izasousakids985@gmail.com.

-• Aluna do Programa de Pós Graduação em Desenvolvimento Socioespacial e Regional da Universidade Estadual do Maranhão, bolsista pela CAPES. Submetido: 23/Abril/2018; Aprovado: 15/Maio/2018.
} 
in the Lesser Antilles in Central America. Thus, the analysis shows how Ramiro Guerra demystifies a whole theory regarding the substitution of the work of the small owner for the cheap labor of the slave. The same author emphasizes that this substitution was not due to a question of races or of climate or even of the superiority of the human will. But due to a purely social and economic cause: the destruction of small property by the sugar estates and the consequent emigration of a social class that would be expelled in a "voluntary" way due to lack of work. Thus, according to Guerra's analysis, the analysis emphasizes that it was not the Antillean climate that drove out the white servants but the capitalist sugar company that would settle in the region, annihilating the small property and eliminating the independent cultivator and converting the robust communities with their own lives in mere low-wage workshops, all for the benefit of metropolises. And also the consequences of this sugar trade in Cuba with the same consequences of the destruction of small-scale agriculture.

KEYWORDS: Latifundium; Labor; Agriculture; Economy.

JEL Classification: Q1.

\section{VIDA E OBRA}

Ramiro Guerra y Sanchez (Batabanó, Havana, Cuba, 31 jan 1880 - Havana, 29 de outubro de 1970) foi um historiador, economista e educador cubano. Ele iniciou seus estudos de graduação em 1893 na Faculdade de Luz Batabanó e colaborou com a causa da independência da cidade. Uma vez que a guerra terminou em 1898, completou seus estudos de bacharelado que foram interrompidas, mas graduando-se em 1900. Pouco depois parte para estudar o curso especial para professores cubanos da Universidade de Harvard, Cambridge, EUA. Em 1911 foi eleito Presidente Regional para Cuba do Bureau Internacional de Documentação para a Educação. Assim, obteve um doutorado em educação na Universidade de Havana, em 1912, e em 1915 ele foi nomeado diretor da Escola Normal de Havana. Ele foi também superintendente provincial de escolas em Pinar del Rio, e em 1926 superintendente geral das escolas da república. Entre 1927 e 1930, atuou como professor de geografia de Cuba, fundado e dirigido por onze anos a revista Pedagógico Cuba em colaboração com o pedagogo Arturo Montori. Guerra foi presidente da Seção de Educação no V Congresso Pan-Americano da Criança em 1927; foi diretor do Heraldo de Cuba entre 1930 e 1932; e secretário da Presidência da República, em 1932, durante a ditadura de Gerardo Machado, sem acabar sua integridade e seu amor por Cuba e sua história. Em 1933, após a queda de Machado mudou-se para Nova York e depois para Gainesville, Flórida, onde culmina o seu trabalho a expansão territorial dos Estados Unidos à custa de Espanha e países latino-americanos. Mais tarde, ele retornou a Cuba em 1939 e serve como assessor técnico da delegação cubana para a primeira reunião de consulta de ministros das Relações Exteriores das Repúblicas Americanas, realizada no Panamá.

De origem camponês e nativo do Sul agrícola da antiga província de Havana, Ramiro Guerra conservou um grande amor pela boa terra cubana que tantos frutos lhe deram. Neste lugar junto aos plantios que seus antepassados e familiares na 
qualidade de arredantários e proprietários desde 1857, passou a sua infância e adolescência presenciando a devastação resultante da guerra da independência (1895-98). Assim, Conheceu a miséria e os horrores da reconcentração decretada por Weyler, que deixaram em sua memória dias dramáticos.

Guerra ficou longe de Cuba em 1933, mas não parou de estudar as questões da indústria açucareira. E pela razão da política comercial restritiva aplicada pelo Congresso dos Estados Unidos para restringir a depressão geral capitalista nos anos de 1929-32. Com isso se dedicou em sua obra sobre a política expansionista norte-americana desde a constituição dos Estados Unidos até o século XVIII na política de Boa Vizinhança. Assim, faleceu em Havana em 29 de outubro de 1970 em sua terra amada, como sempre desejara.

\section{ESCRAVO CONTRA PRODUTORES LIVRES}

Ramiro Guerra neste tópico analisa o caso da ilha de Barbados, onde tivemos um fenômeno significante em relação a substituição do trabalho do pequeno proprietário da região pela mão de obra barata do escravo. Ele analisa essa relação não apenas como um motivo de superioridade de raça e de clima, mas devidamente da superioridade da vontade humana (principalmente dos escravistas de antes e dos latifundiários de hoje), ou seja, motivos que foram puramente sociais e econômicos. Isso significou a perfeita destruição da pequena propriedade pelo latifúndio açucareiro e, consequentemente pela emigração de uma classe social empreendedora e ativa que foi expulsa "voluntariamente" das suas terras para não ficarem em uma condição inferior de vida e sem trabalho.

Dessa forma, Ramiro Guerra destaca a importância de se fazer uma retificação completa dessa historia econômica das Antilhas. Sendo assim, conforme a história não foi o clima antilhano que expulsou os brancos, e sim a empresa açucareira capitalista. A qual buscou rendimentos (lucros) e exterminou a pequena propriedade. Suprimindo o produtor independente e transformando as propriedades em grandes comunidades com vida própria e em meros negócios com trabalhos a preços bem baixos em benefício exclusivo das metrópoles distantes dos banqueiros e comerciantes.

Barbados assim, tinha um sistema estabelecido de distribuição de terras com os produtores, entregava um certo número de lotes a cada servo branco ao término do seu contrato de servidão, mas com esse término a população europeia aumentou rapidamente.

E segundo Guerra, a partir do momento que se começou a ter uma acumulação e terras pelo latifúndio açucareiro, se alteraram também as condições de vida na ilha principalmente para a classe social que era o sustentáculo da colônia (os servos brancos).

A emigração foi iniciada logo em seguida e já se intensificava na década de 1650 a 1660. As autoridades e os vizinhos mais distantes de Barbados se deram conta da verdadeira causa da emigração: a acumulação de terras pelo latifúndio 
açucareiro que impedia de continuar a distribuir os lotes de terras para os servos brancos para cumprirem seus contratos; e também a compra em grande escala pelos mais ricos produtores de açúcar de numerosas propriedades.

As emigrações se dirigiam à ilhas bem próximas a Barbados (Jamaica e Guiana Francesa) todas de clima idêntico ao de Barbados, o que para Guerra comprova que não foram as condições climáticas, e sim as econômicas e sociais que causaram o fenômeno da emigração.

O governador da ilha de Barbados Francis Lord Willoughby compreendeu que a emigração dos colonos brancos seria a ruína da ilha, e isso fomentaria outras colônias rivais de Barbados e a colocaria em situação de perigo, com isso tentou-se manter os emigrante em busca de terras em ilhas próximas. Mas segundo Guerra isso tudo foi inútil porque o latifúndio continuava a expulsar os pequenos proprietários.

Nos primeiros anos o açúcar produziu uma grande riqueza e fortuna na ilha, mas posteriormente começou a provocar a decadência econômica e social que foi um fato fundamental na história das Índias Ocidentais. A população branca que saiu de suas terras por causa do latifúndio começou a decrescer em 1645, e em 1653 já se tinha uma redução em torno de 30.0000 mil habitantes. Em 1668 tínhamos 20.000 mil habitantes; em 1786, 16.167 habitantes. E em 1922 não passava de 15.000 habitantes.

Um escritor em 1667, citado por Harlow trouxe o seguinte quadro da emigração na época em Barbados: "não menos de 12.000 pequenos proprietários foram conduzidos para fora de suas pequenas propriedades e dos seus vizinhos mais ricos" [...] "entre 1643 e 1647, a Nova Inglaterra foram 1.200 emigrantes; para Trindad e Tobago, Virgínia e Suriname entre 1646 e 1658, 2.400 emigrantes; entre 1650 e 1652, a Martinica, Guadalupe, Grenada, Tobago e Curação, 1.600 emigrantes; a Jamaica 3.300 emigrantes".

E mais de 5.000 emigrantes saíram de Barbados em várias expedições para as Ilhas de Barvalento, durante as guerras com os franceses e holandeses poucos retornaram. Em 1667, o êxodo dos servos brancos que foram embora devido à falta de terras foram para a Inglaterra. Em 1670 não menos de 2.000 ex-pequenos proprietários de Barbados foram para outras plantações.

Paralelamente à diminuição da classe social dos pequenos proprietários brancos, veio o aumento constante da população escrava. Em 1636, em Barbados não tínhamos escravos africanos. Em 1643, três anos depois com a introduçãoe fabricação do açúcar havia 6.000 escravos; em 1655 eram 20.000; em 1668 aumentou para cerca de 40.000, dobrando a população branca; em 1792 havia 64.330, e finalmente em 1835 com a abolição da escravidão, 82.000. O que poderíamos imaginar segundo Guerra (1994) que esse tipo de pequenos proprietários brancos poderiam ter permanecido na ilha como uma classe de funcionários, mas a mesma causa econômica que lhes arrancou a terra, fez eles encontrarem um "trabalho".

"O cultivo das grandes plantações exigia o uso de uma mão de obra barata em grande escala" - disse Harlow - "e muito depois os açucareiros puderam perceber, que com o dinheiro necessário para se procurar os serviços de um branco por 10 
anos, eles poderiam comprar um escravo para a vida toda." No início houve a necessidade de se usar a mão de obra do branco, porque os trabalhos exigiam uma certa técnica e habilidade manual, mas assim que os escravos se adaptaram nas atividades o trabalhador branco teve que seguir o caminho da emigração. Ramiro Guerra destaca que não era uma questão de negros ou de brancos, de europeus ou de africanos, mas de trabalho desvalorizado perante um trabalho de maior custo. O problema não era racial, mas social e econômico.

A abolição da escravidão não deixa de suprimir o homem de cor da sua servidão econômica em Barbados, aponta Guerra (1994), ou em qualquer das outras ilhas pequenas, porque como poderemos observar posteriormente, as terras irão continuar nas mãos dos latifundiários, e depois da abolição eles irão se deparar com um verdadeiro dilema idêntico do que aconteceu com o branco (servo): emigrar ou trabalhar por um salário mínimo imposto pelos plantadores. Nem os pobres libertos escravos e seus descendentes menos afortunados do que os filhos dos proprietários brancos conseguiram viver sem violência e sem o "jugo e o ferro" do latifúndio econômico.

O latifúndio açucareiro irá terminar na terceira década do século XX, mas o século XVII foi marcado em Barbados pela fortuna e bem-estar de poucos, a custa da miséria e sofrimento da maioria. A obra de Ramiro demonstrou a servidão econômica do negro e do branco no lugar do cultivo independente.

\section{TERRA E TRABALHO DE GRANDES PROPRIEDADES}

Neste tópico o autor apresenta que os pequenos proprietários de Barbados contribuíram no povoamento de outras colônias nas quais se reproduziram o mesmo ciclo: a acumulação de terras pelos mais ricos plantadores - desaparecimento da pequena e média propriedade; emigração dos produtores brancos e importação de escravos em grande escala.

A organização social e econômica se cristaliza em uma forma definitiva e imutável: acima o produtor latifundiário, abaixo o escravo africano. Não existe nesta sociedade tão simples em sua composição nenhum fator de mudança, de progresso de retificação no sentido de humanidade e justiça. Não se concebe que o proprietário da plantação geralmente um rico comerciante da cidade, ou um senhor com assento no Parlamento se desprenda de uma parte de seus ganhos espontaneamente de suas terras em proveito de uns miseráveis escravos esmagados pelo trabalho e degradados pela servidão.

$\mathrm{O}$ ano de 1833 se produziu uma mudança aparentemente fundamental na ordem social e política: o Parlamento inglês aprovou uma lei de abolição da escravidão restabelecendo como medida preliminar o que segundo o Prof. Mathieson chamou de sistema de aprendizagem ou de patronato. A lei dizia que os menores de 6 anos ficariam livres desde o momento, mas estipulava que os maiores dessa idade deviam continuar como aprendizes durante 6 anos, mas a serviço de seus 
mestres com a obrigação de trabalhar 7 horas e meia diárias para estes, e em troca recebiam alimentação, roupas e alojamento sem acumular nenhum tipo de salário.

$\mathrm{O}$ autor ressalta que a execução desta lei se manifestou um fato fundamental de caráter econômico, social e político: que não tendo o homem de cor terra onde trabalhar como cultivador independente havia de continuar, ainda que depois de inteiramente livre tão oprimido e explorado como antes.

O Prof. Mathieson diz: "triste evidencia, até onde pode chegar o egoísmo humano: a fim de tributar com um forte imposto as terras destinadas a produção de alimentos, a fim de que os negros não tivessem maneira alguma de procurar sua subsistência e se viram forçados a aceitar o salário que era imposto". Mas o latifúndio que faz da agricultura um negócio puramente mercantil requer acima de tudo mão de obra barata.

\section{REDUÇÃO DA INDEPENDÊNCIA ECONÔMICA DE CUBA E EMPOBRECIMENTO DA POPULAÇÃO RURAL}

Como podemos perceber, o latifúndio açucareiro concentrou enormes extensões de terras melhores e cultiváveis em mãos de umas poucas pessoas. Esta comunidade formada em sua maioria por cultivadores e proprietários rurais com a consciência de sua existência e sua personalidade aspirou a uma liberdade política e lutou para alcançá-la sob o poder da Espanha ou fora dela até constituir-se em Estado independente.

O latifúndio é um processo às inversas: funde milhares de parcelas de terra em grandes unidades agrárias, desenraizando o produtor do seu solo, destruindo a classe urbana de proprietários rurais e agricultores independentes, a "espinha dorsal da nação" e finalmente acaba com a autonomia econômica nacional para converter a comunidade em uma mera dependência em uma oficina de trabalho a serviço de uma metrópole econômica exterior.

O latifúndio acaba com o que em quatro séculos se fundou em Cuba, reduzindo um imenso campo de produção de açúcar a baixo preço de utilidade em benefício a proveito do consumidor estrangeiro. O latifúndio açucareiro cubano também ataca a raiz da sua constituição econômica, social e política e vem fatalmente reduzindo as grandes massas do povo cubano à miséria.

O latifúndio ao arrebatar a terra das mãos do cultivador cubano arranca o mais eficaz meio e único de bem-estar de que dispõe o mesmo. O poder coletivo de criar riquezas e de produzir e multiplicar bens vai desaparecendo rapidamente. $\mathrm{O}$ cubano capitalista tende a viver da renda do capital e o cubano pobre do salário diário sem aspirar a nada próprio, quanto mais uma casa no campo ou nos arredores pobres dos povoados. Ele vai atacando e reduzindo progressivamente e fatalmente os meios e vida da classe agricultora cubana mergulhada na pobreza e provocando a sua inevitável decadência física, intelectual e moral. E no que concerne aos empregados e trabalhadores somente têm trabalhado a um curto tempo de 3 a 4 meses. 


\section{VASSALAGEM PROGRESSIVA DO CULTIVADOR INDEPENDENTE E A ESCASSEZ DE TERRAS}

Temos demonstrado que a companhia açucareira latifundiária não investe enormes somas somente para querer adquirir terras por mero desejo de se estabelecer em uma grande empresa, e sim pela necessidade de excluir a concorrência com outro centro e assegurar a provisão da cana sem ter que disputa-la em um mercado livre de colonos ou de cultivadores independentes aumentando a quantidade de açúcar.

A companhia açucareira não investe capital em terras, mas somente o necessário para atingir o objetivo pretendido. Quando garante fornecimento suficiente de cana a terra não interessa mais. Uma vez que a companhia latifundiária possui um numero mínimo de terras calculadas, a necessidade de compra da cana do colono livre desaparece ou diminui muito consideravelmente, e então aproveita a ocasião para reduzir a quantidade de açúcar por cada cem libras de cana que se entrega ao colono independente, colocando-o nas mesmas condições em que o trabalho nas terras do engenho.

Desta maneira o latifúndio vai estendendo sua dominação nas zonas onde prevalece, finalizando em suprimir qualquer propriedade rural do individuo, ou manter uma pequena proporção que permanece numa condição de submissão absoluta.

Toda propriedade rústica situada dentro de um grande latifúndio acaba, pois sendo dominada sem a necessidade de ser comprada pela empresa latifundiária, o colono independente resultará fatalmente como citado acima.

O cultivador de mais ambição e que gosta de trabalhar livremente por conta própria, se não possui terras transporta sua família para uma pequena casa da aldeia central, deixando a vaca leiteira, outras raças domésticas e alguns vegetais perto de casa que garantiam o seu sustento de sua esposa, filhos, em suma, queria ser um homem livre no seu próprio país e manter sua família em condições economicamente e moralmente mais vantajosas.

Dessa forma, Guerra explicita que o latifúndio irá gradualmente sufocando toda a classe cultivadora independente, arruinando e empobrecendo, baixando seu padrão de vida, e principalmente através da criação de condições de vida insuportáveis. E como sabemos a agricultura é a atividade econômica que gera riquezas por excelência, a fonte de vida dos cubanos em todo território nacional e sua riqueza diminui ao mesmo tempo seu poder de compra.

\section{A DECADÊNCIA DO COMÉRCIO E A LIMITAÇÃO DO DESENVOLVIMENTO INDUSTRIAL}

Neste aspecto Guerra (1994) destaca que os males de ordem econômica e social do latifúndio açucareiro que ocorreu nas Antilhas Inglesas estão ocorrendo atualmente em Cuba, afetando em primeiro lugar a classe de agricultores independentes. Então, estamos vendo como o açúcar está criando cada vez mais dificuldades para o comércio, a indústria e o público ferroviário, o que tem causado graves 
prejuízos interrompendo o seu desenvolvimento e ameaçando restringir cada vez mais o seu alcance com prejuízo enorme para a comunidade.

Em Cuba a classe da agricultura empobrece e deprecia as importações salariais de "braceiros" das Antilhas. O latifúndio do açúcar da noite para o dia reduz a capacidade de consumo da classe pobre em geral, determinando a estagnação gradual das atividades comerciais e industriais. E menos comércio e indústria de transporte, há também menos trabalho em todas estas áreas, a situação das classes que dependem de um salário aumenta, criando um círculo vicioso em que foram gerados por vários anos.

\section{O FATALISMO DA REDUÇÃO LATIFUNDIÁRIA:}

\section{A SUPERPRODUÇÃO, DEPENDÊNCIA ECONÔMICA, CRESCENTE EMPOBRECIMENTO DE CUBA}

A companhia latifundiária açucareira cubana para Guerra (1994) se estreita em uma luta infrutífera e inútil (a base da redução e do custo de produção) contra um inimigo poderoso armado com tarifa: a produção do açúcar americano.

A teoria do custo crescente da redução da produção não significou apenas extensão indefinida do latifúndio, da monocultura e dependência econômica de extensão de Cuba, mas salários baixos, pagar menos por seu trabalho, redução constante de renda do produtor e do trabalhador. Um padrão de vida mais baixo e uma situação indefinida de miséria. A colheita foi reduzida e como consequência natural o produtor e os trabalhadores tiveram menos trabalho, menos renda e mais pobreza.

\section{CONCLUSÃO}

Ramiro Guerra ressalta toda uma problemática em torno do latifúndio açucareiro em relação às pequenas propriedades. E desmistifica toda a teoria de explicação em relação a emigração dos cultivadores independentes em Barbados que era colocada em torno de fatores climáticos. O mesmo autor traz elementos como a acumulação de terras pelos grandes proprietários latifundiários como o principal fator de "expulsão" dos trabalhadores, os quais ficando sem opção de trabalho acabavam emigrando para regiões mais próximas de Barbados com o mesmo clima. O que coloca em prova que não era o fator clima, o motivo dessas emigrações e sim as condições sociais e econômicas que estavam atingindo essa classe de pequenos proprietários.

No entanto, o trabalho da agricultura passa a desaparecer em virtude das instalações dos latifúndios açucareiros, o trabalho manual e de subsistência dos pequenos produtores passa a ser eliminado, e os mesmos se encontram obrigados a trabalharem na produção do açúcar com baixos salários.

Em sua obra podemos perceber um certo positivismo e nacionalismo pelas 
terras cubanas. Dando ênfase a uma classe proprietária nativa e presente e não ausente com vocação de fazer um país para ela, demonstra o autor. Poderíamos ter assim a possibilidade de um verdadeiro desenvolvimento nacional. Ele vai por um caminho de apreensão total de um processo histórico de uma visão integrada da sociedade. Dessa forma, não incorre em fáceis conclusões, pelo contrário mostra que Cuba, ainda que seu desenvolvimento houvesse centrado na indústria açucareira, não adquiriu características de uma plantação colonial. Assim, existe uma estreita relação do processo nacional em sua obra.

No entanto, enquanto a região de Barbados perdia a sua população para uma emigração "forçada", o império colonial inglês iria se expandindo e reduzindo a região uma mera colônia de plantação açucareira sem importância política, constituída por "proprietários ausentes e de braços escravos". Dessa forma, o autor enfatiza muito bem a questão dos latifúndios açucareiros serem de proprietários que não são da região e sim de outro país, e que ainda se utiliza de braços escravos.

$\mathrm{O}$ autor lamenta o fato de Barbados ter perdido a sua importância política dentro desse contexto, e nem sabe de que maneira alguns escravos ainda conseguiram juntar-se para encontrar os meios de melhorar a sua situação mediante os seus senhores. Isso implica, ainda que o autor não saiba explicar, uma forma de resistência desse pequeno e restrito grupo que ainda possuía alguma esperança de procurar meios de sobreviver em suas próprias terras.

\section{REFERÊNCIA BIBLIOGRÁFICA}

GUERRA, Ramiro (1994) "Latifúndio, escravidão e dependência econômica”. In MARINI, R.M.; MILlÁN, M. (coords.). La Teoria Social Latinoamericana: Tomo I, De los Orígenes a la Cepal. México D.F.: El Caballito, p.15-46. 